\title{
ENHANCING DRINKING WATER QUALITY IN REMOTE MĀORI COMMUNITIES
}

\section{Climate change, microbes and mātauranga Māori}

\author{
Wendy Henwood* \\ Troy Brockbank ${ }^{\dagger}$ \\ Helen Moewaka Barnes ${ }^{\ddagger}$ \\ Elaine Moriarty \\ Christian Zammit" \\ Tim McCreanor ${ }^{\text {Il }}$
}

\begin{abstract}
This article reports the findings of a two-year transdisciplinary research project that explored the implications of climate change for the security and safety of drinking water supplies in three communities in Te Hiku o te Ika in Aotearoa New Zealand. In this region, potable water comes mainly from "roof and tank" systems. The project was designed as integrative Kaupapa Māori

* Te Rarawa, Ngāi Tupoto, Ngāti Here, Tahāwai. Researcher, Whariki Research Group, Massey University, Auckland, New Zealand. Email: tirairaka@outlook.com

† Te Rarawa, Ngāti Hine, Ngāpuhi. Kaitohutohu Matua Taiao/Senior Environmental Consultant, WSP OPUS, Auckland, New Zealand.

‡ Te Kapotai, Ngāpuhi-nui-tonu. Director, Whariki Research Group, Massey University, Auckland, New Zealand.

$\S$ Senior Research Scientist, Institute of Environmental Science and Research Ltd, Christchurch, New Zealand.

" Hydrologist, NIWA, Christchurch, New Zealand.

^ Researcher, Whariki Research Group, Massey University, Auckland, New Zealand.
\end{abstract}


research utilising climate science, microbiology and social science to develop community-oriented approaches for dealing with the complex issues at the nexus of climate change.

Evidence-based advice and practical suggestions tailored to specific locations were developed by drawing on climate change projections, local mātauranga Māori and drinking water studies. Interviews with kaumātua surfaced long-standing knowledge and experience of the climate and its variations in Te Hiku. Computer-based scenario modelling-using both automated and community-collected data on precipitation and temperature-produced 80-year climate change projections of water security. Health-focused Escherichia coli studies revealed the current water quality and used climate data to predict future water quality. Overall, this research reinforces arguments in the literature that the findings of transdisciplinary studies can provide more explanatory power than single-discipline research.

\section{Keywords}

mātauranga Māori, drinking water, climate change, water quality, security, E. coli

\section{Introduction}

In this article we present the findings of a collaborative and integrative Kaupapa Māori study that utilised climate science, microbiology and social science to understand the challenges of maintaining potable water supplies for remote Māori communities in Te Hiku o te Ika in Aotearoa New Zealand as climate change begins to make an impact. The two-year project was funded by the government's Deep South Challenge (DSC) as part of its commitments to Vision Mātauranga, a government science policy framework. Our aim was to deliver evidence-based advice and suggestions relevant to these long-standing but often impoverished and poorly serviced settlements. Both the climate science and the microbiology elements of the work entailed comparing standardised techniques and systems with relevant measurements systematically recorded by local resident investigators in each community, providing a strand of "reality testing" for conventional science (Henwood, Moewaka Barnes, Zammit, Moriarty, \& McCreanor, 2018).

The researchers conceptualised the entire project within a Kaupapa Māori participatory research framework, providing a basis for community action cycles (Kerr, Penney, Moewaka Barnes, \& McCreanor, 2010) that delivered new knowledge on climate change and drinking water, contributed to capabilities within the participating communities, and produced serendipitous gains from the interchanges among communities and researchers. The outcomes provide inspiration for both institutional researchers and Māori communities as to what can be achieved with integrative work, the kinds of parameters in play and the expectations parties can reasonably have of each other in the context of such collaborations.

We begin by outlining the challenges posed by climate change and its impact on drinking water supply in the small rural settlements in this study. Climate change is threatening the ability of households to provide enough continuously available, safe and clean water for those in residence. We then explore integrative methodologies, discuss how Kaupapa Māori theory aligns with such methodologies, and present the findings from each of the collaborative components of the project. We argue that Kaupapa Māori and integrative theory and approaches form a strong foundation for the constructive work urgently needed to adapt to the effects of climate change, contributing to 
the long-term viability and survival of remote Indigenous communities.

Te Ropu Whariki at Massey University has a long track record of working closely with Māori communities, reflecting its commitment to using the power of Māori public health science to contribute to the aspirations of the people. Through a decades-long association with Te Hiku o te Ika, Te Ropu Whariki is connected to a growing network of Māori researchers with strong links to particular iwi and Māori communities, many of which can trace their origins to the Polynesian voyagers who first settled these lands. Colonisation, immigration and population growth have seen many of these towns and villages decline through politicised economic change, urbanisation, marginalisation and neglect by the Crown (Kearns, MoewakaBarnes, \& McCreanor, 2009; Kelsey, 1995).

Weak economic development, low employment, severely reduced social services and infrastructure divestment (Te Hiku Development Trust, 2014) have left numerous settlements with no reticulated water supply (or wastewater removal), leaving households responsible for their own provision and therefore vulnerable during land- and water-related emergencies. Over $10 \%$ of Aotearoa's population rely solely on roof collection for drinking water (Abbott, Moore, \& Golay, 2011). The characteristic arrangement in such districts is almost exclusive dependence on "roof and tank" systems for each household, meaning that the people are subject to the vagaries of rainfall patterns for the most fundamental requirement of human survival-clean drinking water. Although the storage capacity may have been adequate when installed, it is now commonplace for households and Māori community facilities such as marae to have to pay for expensive tanker loads of drinking water over the summer months, necessitated by changing rainfall patterns.

To these already difficult circumstances, ongoing climate change (Ministry for the Environment, 2016, 2018) adds the unwelcome burden of uncertainty and potentially worsening conditions as Te Hiku begins to experience the hotter, drier patterns of weather that modelling predicts (Ministry for the Environment \& Stats NZ, 2017; NIWA, 2017). Along with other harmful effects of climate change-sea level rise, species migration/extinction, increasing storm intensity, oceanic acidification, for example-lower average rainfall means that already stressed potable water supplies may threaten the viability of households and even whole communities. Adding to these difficulties are the implications of climate trends for the presence and impact of microbial pathogens, particularly those with animal vectors such as birds, opossums and rodents, which commonly contaminate rooftop water collection surfaces. Higher water temperatures in storage tanks provide conditions that favour the proliferation of microorganisms, increasing the danger of infection and enteric illness.

\section{Integrative theory}

Complex, challenging issues of the kind under study require a paradigm shift from the disciplinary, silo-bound practices favoured by entrenched academic science enterprises. Innovative thinking in the area of transdisciplinary or integrative approaches (Bammer, 2015; Wickson, Carew, \& Russell, 2006; Wilcox \& Kueffer, 2008) is generating both rigorous critique and exciting possibilities. Multiple voices (Parkes et al., 2005; Stokols, 2006; Zinsstag, 2012) are arguing for integrative approaches that transcend academic disciplines, institutional practices and state conventions. From their review of literature in the EcoHealth/One Health domain, Min, Allen-Scott and Buntain (2013) outlined critical steps towards transdisciplinarity, stressing the need for research funding, leadership, conceptual work, capability building, participatory methods and evaluation of initiatives. In the context of this article, the convergence of social, ecosystem and climate change research is revealing the 
influence of these factors on the health and wellbeing of human and animal populations.

Our research design therefore speaks to the expressed priorities for the fields under study. While not attempting a formal evaluation of the outcomes of the project, we do report on the successes we achieved and challenges we encountered in the hope that our account will be of interest and value to others with similar aims.

\section{Research setting}

Te Hiku o Te Ika is the territory of five northern iwi-Ngāti Kuri, Ngāti Kahu, Te Aupōuri, Te Rarawa and Ngāi Takoto-that spans from the north shore of the Hokianga Harbour, including the vast Mangamuka and Warawara ranges, and the Aupouri Peninsula, up to the northernmost point of the country, Te Reinga. Four of these tribes completed a Treaty settlement process that returned assets in land, cash and other resources in late 2015. As noted above, neglect and exploitation of the area by the Crown has left the population, environment and infrastructure in poor shape, and over the years a number of initiatives attempted to address problems in health, education, employment, economic development and sustainability. These culminated in the Te Hiku Social Accord (Te Hiku Iwi Development Trust, 2013) between the Crown, 11 ministries and agencies, and Te Hiku Iwi Development Trust-a collective settlement mechanism comprising trustees appointed by each participating iwi. Among other things, the Accord produced the Te Hiku Well Being Report (Te Hiku Iwi Development Trust, 2014), which details disparities between the district and the rest of the country and acts as a baseline for monitoring progress for Māori of the rohe.

In 2016 the DSC undertook a contestable funding round, calling for proposals that related to parameters of climate change and Vision Mātauranga. Vision Matauranga is a policy document embedded in the Ministry for Business Innovation and Employment's investment processes, outlining a number of expectations around relationships, Māori knowledge and capability (Ministry of Research Science and Technology, 2007). Within the DSC, the Vision Mātauranga science programme focuses on the implications of changing climate conditions for Māori society. After some consultation and debate, the research team, comprising three social scientists, a climate scientist and a microbiologist, suggested a focus on participatory action and water. In discussion with community members and the DSC, the research settled on potable water supplies in unreticulated Māori communities, a widely acknowledged problem in terms of safety, inconvenience and expense (NIWA, 2017). This led to more detailed discussions about the participation of three communities. Motukaraka, Pawarenga and Te Kao-spanning some 125 kilometres on an approximately north-south axis (see Figure 1)—all agreed to join the drinking water monitoring and community participatory project.

Motukaraka is a community on the north shore of the Hokianga Harbour, centred on the Ngāi Tupoto Marae. Here we recruited 26 households (84 people) that were exclusively reliant on roof and tank supplies for drinking and other water. At Pawarenga, a coastal settlement about 45 kilometres northwest of Rawene, we engaged 36 households (114 people), most of which are dependent on roof and tank systems with an additional supply for marae from a small lake situated in the Warawara Forest. At Te Kao, which is about 65 kilometres north of Kaitaia, we worked with 32 households (86 people), and again roof and tank systems were their primary source of drinking water.

\section{Methodology}

Within a broad Kaupapa Māori participatory research framework (Kerr et al., 2010) that 


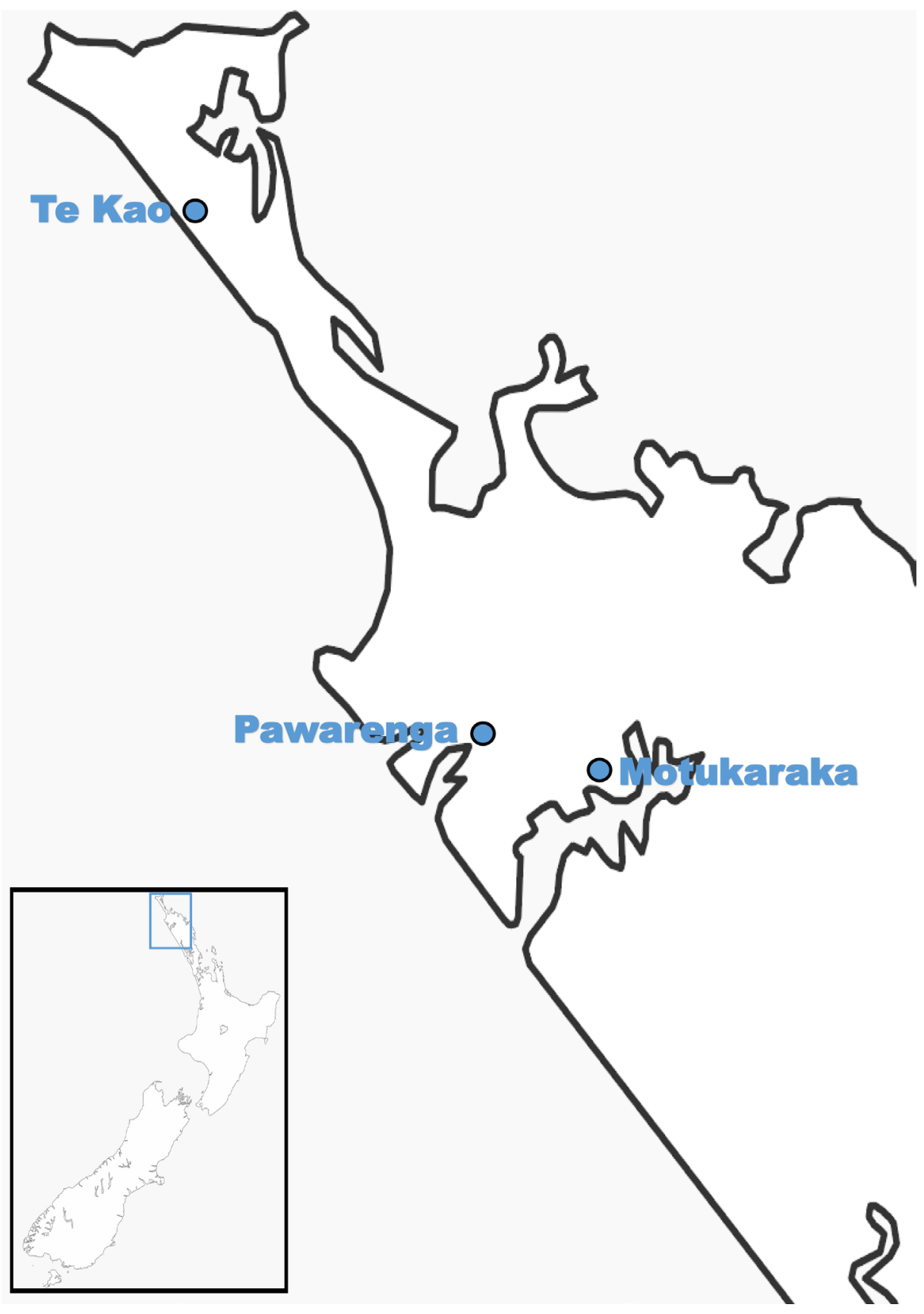

FIGURE 1 Map of Te Hiku region showing the location of the study communities: Motukaraka, Pawarenga and Te Kao

encourages and supports community engagement, we focused on the ability of households to provide enough safe, clean water for residents. In each participant community, we needed to consider water supply systems and how key dimensions of climate change might affect them in order to produce a suitable research design to explore the local issues around security and safety of drinking water. The study aimed to develop knowledge as a basis for action, bringing community participation into collaboration with social scientists from Massey University (Wendy Henwood [WH], Helen Moewaka Barnes, Tim McCreanor), a microbiologist from the Institute of Environmental Science and Research (Elaine Moriarty [EM]), a hydrologist 
from a commercial entity (Troy Brockbank; also of local iwi) and a NIWA climate change modelling specialist (Christian Zammit). WH lives and is well known within the research site communities and was able to provide regular support to the community researchers.

To meet the aims of the project and build community capability, we developed a threepart design involving the security and safety of water supply and mātauranga Māori. We used multiple methods, including qualitative interviews, climate scenario impact modelling and drinking water surveys. Team discussions synthesised understandings from all sources as we explored a range of predictions, options and challenges to develop both critical insights and practical suggestions to address drinking water issues at household and community level.

\section{Drinking water security research design}

This part of the project involved scenario modelling to create locality-specific predictions for climate change in Te Hiku. We used the average of six pre-existing climate models that were based on slightly different assumptions about the changes entailed in climate change (Henwood et al., 2018; Ministry for the Environment, 2016). All the projections (that is, the regional-scale climate models) were downscaled monthly based on the monitored difference between regional current climate data from NIWA's Virtual Climate Station Network (VCSN) and local weather conditions (community researchers). The findings also contributed to the development of a user-friendly aid to decision-making tool for adjusting household and community roof water supply parameters, functions of household population requirements, and roof water supply system design.

\section{Drinking water safety research design}

Two key elements of the project were designed to shed light on local issues that might affect the quality of drinking water in community households. A household infrastructure survey was adapted from earlier surveys used by team members to understand amenities and issues impacting on household water supply. Through discussions with community researchers, the survey was adjusted to explore water quality and tailored for the communities under study. The survey consisted of a site visit to each participating household in each community, where observations of roof, guttering, pipes and tank were made and a questionnaire completed by householders.

For the second strand of the investigation, laboratory testing for Escherichia coli (E. coli) was planned for samples taken from kitchen supply taps in participating households. The original intensive sampling design was modified due to logistical difficulties and the cost of getting samples to the laboratory. As a result, the study became a field-pilot for the use of a commercially available home watertesting kit known as the Compartment Bag (CB) test, which was developed in the United States by Aquagenx (2018). To the best of our knowledge, this was the first field test of the technology in Aotearoa, and our research therefore pioneered the use of affordable, userfriendly testing of drinking water by community people and researchers.

\section{Participatory research design}

Kaumātua interviews were conducted to give longer-term perspectives on climate change and/ or variability, and also to promote discussion of the topic in communities. As noted above, collaborative work between professional and community researchers was central to the participatory design of this component, which involved integrating the several strands of investigation. Community researchers gathered the temperature and precipitation data (used to bias-correct regional information to local settings) on a daily basis, carried out the water infrastructure surveys in each community, and 
completed the sample collection for both laboratory and $\mathrm{CB}$ testing as well as undertaking the $\mathrm{CB}$ measurements. Hui and other networking processes were used to engage the communities and present an outline of the research designs, report findings and discuss mitigating actions.

\section{Findings}

Data were collected for each strand and analyses were synthesised to address the aims of the study. The findings from each strand of the research are presented below.

\section{Drinking water security modelling}

Temperature and precipitation data were generated from VCSN, which generates (based on existing climate information) automated climate information at 5-kilometre nodes on a grid that overlies the entire country (Tait, Henderson, Turner, \& Zheng, 2006). To account for local variation in these measures, a community researcher in each location recorded temperature and rainfall daily for 18 months. Our analyses showed that there were some interesting divergences between the automated and the manual datasets. We computed monthly adjustments of precipitation and temperature for each locality before running analyses within the climate projections. What follows are brief descriptions of what we learned for each location, together with NIWA's end-of-century projections for changes in temperature and rainfall.

At Te Kao the local average monthly measurements for temperature differed from the VCSN data by up to 5 degrees Celsius, while rainfall measurements varied by up to 1.4 millimetres per month, with annual precipitation at 1,343 millimetres. At Pawarenga, average temperatures were up to 12 degrees higher than the VCSN estimation (potentially reflecting of the location of the local monitoring point) and up to 2 millimetres greater for precipitation with the cumulative total at 1,927 millimetres.
For Motukaraka, the variance was up to 6 degrees and 1.4 millimetres for precipitation, with annual rainfall of 1,766 millimetres. The community-based research was invaluable in that it highlighted temperature and rainfall variations across different locations within Te Hiku. The rainfall data show a difference of nearly 600 millimetres per annum between Te Kao and Pawarenga, while the temperature range shows the latter has a warmer microclimate.

The climate projections based on the scenario modelling spanning a 20-year time slice centred to mid-century (2040s) and end of century (2090s) suggest that temperature will increase across the rohe by $1-3$ degrees by the end of the century. The aid to decision-making tool can be tailored for any time slice, but we worked with the above two for consistency with Ministry for the Environment frameworks. Our findings also predict that, while rainfall volumes may be similar, patterns may be different; precipitation overall will tend to decrease but in mid-summer it is likely to increase due to extreme weather events. The modelling suggests that by the end of the century there will be an increase in the annual volume of roof-available water of up to $20 \%$ for roof water tanks. While this may seem to contradict the use of the broad notion that the climate will be "drier", this term is still appropriate because, except for extreme events in the summer months, the overall outcome will be less precipitation.

\section{Drinking water safety}

The household survey was developed to obtain information about household occupancy, water system infrastructure and issues of concern about drinking water in each of the project locations. Community researchers carried out the questionnaires to 94 households (inhabited by 284 people) across the three communities. The surveys provided quantitative data relating to drinking water storage and delivery. Collation of the surveys across the three communities revealed that many households supplemented 
roof water with puna supply and commercially purchased drinking water. The lack of certainty around a sustainable supply of drinking water was of concern to many participants. The ability to maintain water infrastructure was also a major concern across all three communities; cost and access were cited as the main problems for these isolated communities. Many individual household systems-tanks, roofs, guttering, pipes-needed urgent repair or even replacement, and there was a need for additional water storage.

Reports of contamination of roof water supplies from road dust, pine pollen, animal fouling, agricultural fertiliser, pesticide and weed control sprays were commonplace; many households in one community talked about a 1080 rodent poison drop in the locality. In some instances, water was described as discoloured, smelly or muddy during particular climatic conditions or weather events.

Responses demonstrated the resourcefulness of the people who made the best of what they had. Some had installed small additional tanks for outdoor supplies and saved grey water for garden use. Many whānau boiled their drinking water as a precaution and a few had filtering systems. There were whānau who never ran out of water by conserving and managing their supply, particularly during droughts.

The second strand of the research design around the safety of water supply involved testing household drinking water sources for microbes. EM provided a list of significant organisms that could contaminate supplies. We decided to focus exclusively on the bacterial indicator of water quality, E. coli. This organism is an appropriate species to monitor because it is waterborne, commonplace in the environment, concentrated in animal faeces, relatively easy to test for, and a useful indicator of the presence of other, less common, harmful pathogenic microorganisms.

While our intention was to use laboratory testing for E. coli, as noted above, the logistics rendered this impractical and expensive, so EM searched for alternatives and recommended the $\mathrm{CB}$ test, which allowed E. coli measurements to be carried out in the community. The CB test involved adding the sampled water to the supplied compartment bag and then placing it in the incubator provided with the kit for 24 hours. Any change to a blue/green range in the bag indicates E. coli presence and the level of contamination is assessed by colour matching with the chart supplied. The reliability of the CB test was validated through testing a smaller set of water samples at a local laboratory to compare with the CB test bags. We found a strong match between the results from laboratory and $\mathrm{CB}$ testing, which is a potentially invaluable breakthrough that could be of great interest to many rural community settings where water testing presents significant logistical challenges.

For the household testing, EM provided the equipment and instructions on the use of the $\mathrm{CB}$ test to $\mathrm{WH}$ and the community researchers at each site. Each community researcher took water samples from six households in the three communities and repeated the sampling weekly over three weeks, conducting 54 tests in total. The results of the $\mathrm{CB}$ testing showed that E. coli counts in the community samples from Te Kao ranged between 0 and 6 organisms per 100 millilitres of water. Very similar data were reported from Pawarenga, where the range was between 0 and 5 organisms per 100 millilitres. There was a contrast between these readings and those for Motukaraka, however, where four CB test readings showed up to 100 organisms per 100 millilitres of water, giving cause for concern. The Drinking-water Standards for New Zealand (Ministry of Health, 2008) state that a level of less than 1 E. coli organism should be present in 100 millilitres of drinking water. This is to ensure the water is safe for human consumption and will not result in any ill-health effects to the consumer.

To examine the Motukaraka results more closely, a further nine CB test samples from five homes were taken. This was followed with samples taken for laboratory testing from four 
homes. These results concurred with the $\mathrm{CB}$ test findings, and the households were advised of the results and possible remedies, including boiling supplies, while longer-term solutions were put in place.

\section{Kaupapa Māori participatory research}

We now report on two integrative components that grounded the research in community-based knowledge, needs and possible actions. Both have the potential for wider applicability.

\section{HE MĀTAURANGA NŌ TE HIKU}

In this section we report the experiences and knowledge of local kaumātua who shared their stories for the project. They had lived on the land in the participating communities most of their lives; one kaumātua was 94 years of age and had never lived anywhere else. Water was viewed holistically so that household drinking water could not be viewed in isolation. It was a taonga "that was precious, and it still is precious". Drinking water was part of the environment, the land and the people, and had whakapapa to Rangi-nui and Papatūānuku.

Participants always observed and lived by the weather, acknowledging the vital connection between climatic conditions and the environment. Their experiences and observations included knowledge related to farming, gardens, orchards and fishing. Water was the basis for land-use decisions, and lifestyles revolved around water, both fresh and salt. While climate change and the part that people had played in it were acknowledged, kaumātua had grown up working with the natural environment and had local knowledge and mātauranga to guide and prepare for any adaptations required. Kaumātua saw climate change as nature's response to man-made change, and therefore they had an obligation to work with it. They cited the whakatauki "tiakina te taiao, tiakina te iwi" (look after the environment, and it will look after the people).

The changes to local water catchments were seen as having a major influence on both supply and quality. Unseasonal weather, particularly torrential rain, was blamed for siltation that affected the rivers, harbours and the sea connected to the three communities. The biggest change kaumātua identified was that the seasons were now unpredictable and no longer distinct. They described stronger-than-usual winds and flood events that could arrive at any time, rather than being usually confined to winter.

People who fished regularly were acutely aware of change and concerned about the impact on whānau who relied on the sea to feed their families. Seasons determined local kaitiakitanga practices and harvest times. White-baiters noticed seasonal changes affecting the cycle of that species; the season used to be June-July in one community, and it is now late August and September. The timing of gardening and farming routines had also changed, and this has begun to impact on the ability of whānau to be self-sufficient. The impact of the storage life of vegetables such as potato and kūmara, which need dry summer conditions leading up to harvest, was noted. The current climatic conditions had also seen an increase in new pest species (flora and fauna) and diseases.

Kaumātua clearly made the connection between climate change and detrimental landuse practices of the past and present. Using and caring for the land in ways that enhanced the environment and mitigated climate change posed challenges for communities in areas of high unemployment and minimal infrastructure. Maintenance of household water supply infrastructure was not a priority where households were struggling in difficult socioeconomic conditions; upkeep tended to be crisis-driven rather than preventative.

Water that came from mountains and native bush areas provided a level of security. Kaumātua recalled sustainable water supplies from various sources, including drawing from puna for distinct purposes such as cowsheds, households and gardens. They were considering reinstating 
local puna for supply. This meant drawing on knowledge passed down to them about the ways their catchments worked, and their responsibility to maintain rangatiratanga over the land. As one kaumātua reflected: "Change isn't new in Te Hiku; people are resourceful.”

\section{COMMUNITY HUI}

Two gatherings were held in Kaitaia, and site visits were made to each of the three communities. The first Kaitaia meeting involved discussion of the issues, research design, community engagement and benefits of the project. The second outlined the findings and explored options for dealing with the challenges presented by climate change.

In terms of water security, two main possibilities surfaced: increasing storage capacity at household level and investing in communitybased reticulation, from either local sources or regional supply. These options require financial outlays by households or by community organisations to mobilise common resources, although community initiatives could help keep the costs down through bulk purchasing options.

In terms of safety, a number of actions that could occur at household level were discussed, beginning with repairs and maintenance, tidyingup of overhanging vegetation, upgrade of pipes, de-sludging of tanks and ensuring sufficient distance from septic tank fields or other potential sources of pollution. Another initiative well worth pursuing is the use of first-flush diverters. These are inexpensive, self-installed devices that redirect the initial water to fall on a roof to another storage tank for productive use in gardens. This automated system effectively washes the roof, disposing of the contaminated "first flush" before delivering the rest of a rainfall event into the household drinking water storage tanks. More expensive, high-tech solutions involve filtration at the tap-a cost of hundreds of dollars-or ultraviolet treatment that can cost thousands and involves other expenses in terms of retro-fitting equipment.

It might also be useful to consider partial solutions that reduce the load of microbes arriving on water collection surfaces. Possum and rat trapping by households would cut down on the rooftop traffic of these animals and thereby the amount of faecal contamination. Ongoing monitoring using the $\mathrm{CB}$ test can be implemented at community or household level to test for E. coli presence and ammonia. Proprietary products can then be applied to reduce microbe counts as required (HealthEd, 2018). In the absence of any of these actions, the old recourse to the boiling of drinking water is a fail-safe way of eliminating microbial contamination.

\section{Discussion}

This integrative research project brought together local mātauranga Māori, Kaupapa Māori social science, microbiology and climate science to improve our understanding of the complex issues related to Te Hiku drinking water supplies-the infrastructures, the pressures and the threats-in the context of climate change. We argue that the transdisciplinary approach we adopted was able to deliver deeper insights than the individual knowledge components could have done on their own and-critically—that it has resulted in highly practical suggestions and advice. The prevailing opinion that climate change accentuates certain vulnerabilities for communities and will continue to do so is reinforced by our findings.

This research project ran over a two-year period. During this time, through a combination of discussion, engagement, participation, employment, hui and interviews, we raised awareness of, interest in and preparedness for climate change in general and drinking water security and safety in particular. The work enhanced and increased research capability and capacity within the communities involved, with community researchers carrying out significant parts of the climate measurement, infrastructure survey and $\mathrm{CB}$ testing. In this way the research helped to grow their sense of the value 
of research when conducted appropriately within Kaupapa Māori guidelines.

The research team is developing other publications focusing on the CB test, because its user-friendly character and low cost $(\$ 10)$ per test were crucial to this study, and it is likely to be of interest to a wide audience. We believe it will be particularly valuable in remote communities where drinking water safety is an issue in both private homes and public institutions such as marae, schools and community amenities.

The research showed that the people of $\mathrm{Te}$ Hiku are adaptable and resourceful in the face of environmental change, and that they have always understood the importance of managing resources sustainably. From the final hui we understood that the communities want to make use of the findings to improve drinking water security and safety in their homes and lives. We hope that this article, backed by the technical report written for our funders, will be of use and inspiration to policy-makers within and beyond Te Hiku as the country works together to prepare for and adapt to climate change. The findings are highly relevant for communities lobbying local authorities for long overdue improvements needed to ensure secure and safe drinking water supplies.

With climate change an advancing reality, security and safety of drinking water are key concerns for remote rural communities. The outcomes from the E. coli monitoring studies converge with the climate change findings to signal increased risk of contamination going forward. Higher average air temperatures combined with decreasing general rainfall (excluding specific storm events) mean higher water storage temperatures with water being held for longer periods in tanks, providing the conditions under which microbes can multiply to unhealthy levels in drinking water. Despite the generally low levels of E. coli found in the drinking water samples in this study, the above convergence suggests that the risk of microbial contamination of existing water supplies in these communities will continue to grow and that preventative measures should be considered urgently.

The remoteness of Te Hiku communities and the inadequacy of local authority investment in reticulated supplies of drinking water have been highlighted by the findings of the household survey conducted for this research. In terms of supply, the forecasting of hotter, drier conditions seasonally offset by heavier rainfall events suggests a need for greater storage capacity and possibly greater downpipe diameters to optimise the use of such downpours. In relation to safety, the household infrastructure maintenance and the use of filtration to minimise microbe contamination via animal vectors will be increasingly important as ambient temperatures rise.

Although the predictions are for change, being forewarned with knowledge specific to communities or regions increases the confidence with which populations can approach adaptation. While our findings revealed confidence on the part of communities in being able to adapt to climate change, they also raise questions about addressing the issues in practical terms, given resource issues and support needs. This is reinforced by the conditions highlighted in the study in relation to roof and tank water systems and the tendency for these systems to be repaired or dealt with at crisis points rather than regularly maintained, putting people's health at increased risk. The climate change predictions suggest that these systems are likely to be viable as long as we invest in the safety and the sustainability of supply. These individual systems can be more cost-effective and leave communities less vulnerable to adverse events than supply systems that require large infrastructure development. We argue that this investment needs to be systematic and not rest solely on individual households that are already stretched. 


\section{Conclusion}

The research reported here explored the significant challenges to the security and safety of drinking water presented by climate change in the form of higher average temperatures and lower regular rainfall in small rural settlements in Te Hiku o te Ika. The integrative methodology and participatory Kaupapa Māori methods used produced grounded findings in each community, which can be used to adapt to this aspect of climate change. The findings show that Kaupapa Māori integrative approaches provide a strong foundation for the constructive work urgently needed to meet the challenges and contribute to the long-term viability and survival of remote Indigenous communities.

\section{Glossary}

$\begin{array}{ll}\text { Aotearoa commonly used as Māori } & \\ & \text { name for New Zealand; lit. } \\ & \text { "the land of the long white } \\ & \text { cloud" } \\ \text { hui } & \text { gathering, meeting } \\ \text { iwi } & \text { tribe, nation }\end{array}$

\begin{tabular}{|c|c|}
\hline kaitiakitanga & guardianship \\
\hline kaumātua & elders \\
\hline Kaupapa & based within a Māori \\
\hline Māori & worldview \\
\hline kūmara & sweet potato \\
\hline Māori & Indigenous peoples of \\
\hline marae & $\begin{array}{l}\text { Aotearoa New Zealand } \\
\text { ceremonial courtyard; can } \\
\text { include surrounding } \\
\text { buildings }\end{array}$ \\
\hline $\begin{array}{l}\text { mātauranga } \\
\text { Māori }\end{array}$ & Māori knowledge \\
\hline Papatūānuku & $\begin{array}{l}\text { Earth mother, wife of } \\
\text { Rangi-nui }\end{array}$ \\
\hline puna & underground spring \\
\hline rangatiratanga & $\begin{array}{l}\text { right to exercise authority, } \\
\text { chiefly autonomy }\end{array}$ \\
\hline Rangi-nui & $\begin{array}{l}\text { sky father, husband of } \\
\text { Papatūānuku }\end{array}$ \\
\hline rohe & $\begin{array}{l}\text { territory, area, border (of } \\
\text { land) }\end{array}$ \\
\hline taonga & gift, treasure; precious \\
\hline $\begin{array}{l}\text { Te Hiku o } \\
\text { te Ika }\end{array}$ & $\begin{array}{l}\text { The Far North of } \\
\text { New Zealand }\end{array}$ \\
\hline whakapapa & genealogy \\
\hline whakataukī & proverb \\
\hline whānau & extended family \\
\hline
\end{tabular}




\section{References}

Abbott, S., Moore, R., \& Golay, F. (2011). The role of rainwater tanks in reducing vulnerability during land and water related emergencies. Retrieved from https://www.waternz.org.nz/Attachment? Action=Download $\&$ Attachment_id=990

Aquagenx. (2018). The Compartment Bag Test (CBT) quantitative E. coli water quality test kits. Retrieved from https://www.aquagenx. com/e-coli-test-kits

Bammer, G. (2015). Transdisciplinarity: Overcoming fragmentation and powerlessness. GAIA: Ecological Perspectives for Science and Society, 24(3), 145. http://doi.org/c5hn

HealthEd. (2018). Water collection tanks and safe household water. Retrieved from https://www. healthed.govt.nz/system/files/resource-files/ HE10148_Water\%20collection\%20tanks\%20 and $\% 20$ safe $\% 20$ household $\% 20$ water.pdf

Henwood, W., Moewaka Barnes, H., Zammit, C., Moriarty, E., \& McCreanor, T. (2018). Te Hiku o te Ika Climate Change Project: Report to Deep South National Science Challenge. Auckland, New Zealand: SHORE \& Whariki Research Centre, Massey University.

Kearns, R., Moewaka-Barnes, H., \& McCreanor, T. (2009). Placing racism in public health: A perspective from Aotearoa/New Zealand. GeoJournal, 74(2), 123-129. http://doi.org/fvzj38

Kelsey, J. (1995). The New Zealand Experiment: A world model for structural adjustment? Auckland, New Zealand: Bridget Williams and Auckland University Press. http://doi.org/bgf7

Kerr, S., Penney, L., Moewaka Barnes, H., \& McCreanor, T. (2010). Kaupapa Maori action research to improve heart disease services in Aotearoa, New Zealand. Ethnicity and Health, 15(1), 15-31. http://doi.org/bb72v9

Min, B., Allen-Scott, L., \& Buntain, B. (2013). Transdisciplinary research for complex One Health issues: A scoping review of key concepts. Preventive Veterinary Medicine, 112(3), 222229. http://doi.org/f5jgxc

Ministry for the Environment. (2016, June). Climate change projections for New Zealand snapshot. Retrieved from http://www.mfe.govt.nz/sites/ default/files/media/Climate\%20Change/climateprojections-snapshot.pdf

Ministry for the Environment. (2018). Climate change projections for New Zealand: Atmospheric projections based on simulations undertaken for the IPCC 5th Assessment, 2nd edition. Retrieved from http://www.mfe.govt.nz/sites/default/files/ media/Climate \%20Change/Climate-changeprojections-2nd-edition-final.pdf

Ministry for the Environment \& Stats NZ. (2017). New Zealand's Environmental Reporting Series: Our atmosphere and climate 2017. Retrieved from http://www.mfe.govt.nz/sites/default/files/ media/media/our-atmosphere-and-climate2017-final.pdf

Ministry of Health. (2008). Drinking-water standards for New Zealand 2005 (revised 2008). Wellington, New Zealand: Author.

Ministry of Research Science and Technology. (2007). Vision Mātauranga. Retrieved from https://cdn. auckland.ac.nz/assets/uoa-campaigns/abetterstart/documents/VM-Booklet.pdf

NIWA. (2017). Ngai Tupoto Marae water usage monitoring report for period April 2014-March 2015 (NIWA client report 2017352HN). Auckland, New Zealand: Author.

Parkes, M., Bienen, L., Breilh, J., Hsu, L.-N., McDonald, M., Patz, J., . . Y Yassi, A. (2005). All hands on deck: Transdisciplinary approaches to emerging infectious disease. EcoHealth, 2(4), 258-272. http://doi.org/cdzw5g

Stokols, D. (2006). Toward a science of transdisciplinary action research. American Journal of Community Psychology, 38(1-2), 79-93. http:// doi.org/ccqs2n

Tait, A., Henderson, R., Turner, R., \& Zheng, X. (2006). Thin plate smoothing spline interpolation of daily rainfall for New Zealand using a climatological rainfall surface. International Journal of Climatology, 26(14), 2097-2115. http://doi.org/bpcdn7

Te Hiku Iwi Development Trust. (2013). Te Hiku Social Accord. Retrieved from http://www. tehiku.iwi.nz/social-accord.html

Te Hiku Iwi Development Trust. (2014). Te Hiku well being report: Te oranga o Te Hiku. Retrieved from http://www.tehiku.iwi.nz/ uploads/7/4/6/3/7463762/e-copy_-_te_hiku_ wellbeing_report.pdf

Wickson, F., Carew, A., \& Russell, A. (2006). Transdisciplinary research: Characteristics, quandaries and quality. Futures, 38(9), 10461059. http://doi.org/dv592n

Wilcox, B., \& Kueffer, C. (2008). Transdisciplinarity in EcoHealth: Status and future prospects. EcoHealth, 5(1), 1-3. http://doi.org/cq6nst

Zinsstag, J. (2012). Convergence of EcoHealth and One Health. EcoHealth, 9(4), 371-373. http:// doi.org/c5hp 